\title{
THE COMMON COMMERCIAL POLICY AFTER LISBON: ESTABLISHING PARALLELISM BETWEEN INTERNAL AND EXTERNAL ECONOMIC RELATIONS?
}

\begin{abstract}
Angelos Dimopoulos*
Summary: This article examines how the substantive changes brought by the Lisbon Treaty with regard to the scope and nature of Community competence and to decision-making rules in the field of the Common Commercial Policy fulfil the need for balancing internal and external action and stand up to the requirements of international economic regulation. It is argued that the Lisbon Treaty, building upon the premises of the current regime, constitutes a benchmark in the evolution of the Common Commercial Policy. The expansion of the scope of the Common Commercial Policy to trade in services, commercial aspects of intellectual property and, most importantly, foreign direct investment indicates that a common policy in the fields of goods, services, establishment and capital with regard to third countries is necessary in order to serve the goals of internal integration and to increase the competitiveness of Europe in the world. Furthermore, by "merging" the different aspects of the Common Commercial Policy and simplifying the provisions concerning the exercise of EU competence, the Lisbon Treaty ensures its effective application. However, the "merger" of the different aspects of the Common Commercial Policy does not affect the balance of powers that exists in the internal market with regard to the same areas of law. The only derogations from parallelism between internal and external powers concern the exclusive nature of EU competence and the role of the European Parliament. However, these are both necessary for preserving the effectiveness of Union policy and introducing legitimacy in the most important field of EU external relations.
\end{abstract}

\section{Introduction}

The Common Commercial Policy has been one of the most important and dynamic fields of EU external relations. Since its inception in 1957, the scope of the Common Commercial Policy has been significantly changed in order to adapt to the new realities of international trade and economic relations. During the 1990s, the Common Commercial Policy was the subject of significant amendments. In Amsterdam and in Nice, the scope of the Common Commercial Policy was expanded and a com-

*Angelos Dimopoulos, LLM (Cantab), MLE (Hanover), PhD Candidate (EUI). 
plex and ambiguous system of rules was created. In order to strengthen coherence in the formation and application of the Common Commercial Policy and to clarify the complex system created after Nice, the Constitutional Treaty ${ }^{1}$ and subsequently the Lisbon Treaty ${ }^{2}$ introduced new provisions concerning the Common Commercial Policy within the general framework of EU external action.

The evolutionary character of the Common Commercial Policy reveals that EC external trade and economic relations have undergone major changes in order to adapt to internal and international challenges. The demands of globalisation and the trend towards the liberalisation of international economic regulation, as mainly expressed by the formation of the WTO, required an expansion of EC trade policy towards other fields of economic activity. This trend was also supported by the completion of the internal market, which demanded the formation of a common external economic policy beyond trade in goods. The Treaties of Amsterdam and Nice presented the first steps towards building a coherent external trade and economic policy. The Lisbon Treaty attempts to fill the remaining gaps and simplify the rules on the Common Commercial Policy.

Signed on 13 December 2007, the Lisbon Treaty amends the EC and the EU Treaties and provides a new constitutional charter for the EU. After the stalemate and eventual failure of the Constitutional Treaty, the IGC in Lisbon finalised a new version of the founding Treaties which includes significant institutional and substantive changes. An important field of EU/EC action which is the subject of important changes is EU external relations. The Lisbon Treaty, following the pattern of the Constitutional Treaty, merges all fields that formerly came under EC external action into a single chapter of the new Treaty on the Functioning of the European Union (TFEU), and links it with the chapter on external action in the EU Treaty (TEU) with the aim of enhancing consistency and unity in EU external relations. ${ }^{3}$

The Common Commercial Policy constitutes a field of EU external action subject to the same principles and objectives as well as the same institutional rules that establish a common framework for EU external action. ${ }^{4}$ Aiming at clarifying and simplifying the complex rules of Article

1 Treaty Establishing a Constitution for Europe [2004] OJ C310 of 16 December 2004.

2 Treaty of Lisbon amending the Treaty on European Union and the Treaty establishing the European Community, signed in Lisbon, 13 December [2007] OJ C306 of 17 December 2007.

3 For an overview of the constitutional framework of EU External Relations under the Constitutional Treaty see M Cremona, A Constitutional Basis for Effective External Action? An Assessment of the Provisions on EU External Action in the Constitutional Treaty, EUI Working Paper Law No 2006/30.

4 Article 205 TFEU states that 'the Union's action on the international scene, pursuant to this Part, shall be guided by the principles, pursue the objectives and be conducted in 
133 TEC, the new Article 207 TFEU brings significant changes to the scope of the Common Commercial Policy, to its nature and its objectives. It is noteworthy that the Lisbon Treaty kept the text of the Constitutional Treaty on the Common Commercial Policy almost intact. Changing only the references to Treaty Articles and legal instruments, the IGC in Lisbon confirmed the need to change the Common Commercial Policy, thus rendering the negotiating history of the Constitutional Treaty relevant for the interpretation of the provisions introduced by the Lisbon Treaty.

During the negotiations of the Constitutional Treaty, the European Convention dealt with the need for reform of the Common Commercial Policy based on the principles of effectiveness, simplification and legitimacy. ${ }^{5}$ The problems posed by the ambiguous provisions on decisionmaking and the exceptions to the Gualified Majority Vote (QMV) rule, the reduced role of the European Parliament, the confusing references to shared competences and the need for extension of the scope of the Common Commercial Policy to include foreign investment were the major issues that were discussed at the European Convention. ${ }^{6}$ Acknowledging the existence of divergent proposals on these issues, the final draft of the Constitutional Treaty was a compromise between those opting for a farreaching expansion of the Community's role and those favouring only a slight expansion of the Community's tasks, safeguarding the interests of Member States in the field.

This article examines the substantive changes brought by the Lisbon Treaty with regard to the scope, the nature and the exercise of EU competence. Taking into account the evolutionary character of the Common Commercial Policy, this article focuses on the delimitation of powers and discusses how the Lisbon amendments fulfil the need for balancing internal and external action ${ }^{7}$ and stand up to the requirements of international economic regulation. ${ }^{8}$ Within this framework, an analysis of

accordance with the general provisions laid down in Chapter 1 of Title $\mathrm{V}$ of the Treaty on European Union'.

5 European Convention, summary of the meeting held on 15 October 2002 of Working Group VII, CONV/356/02.

6 M. Krajewski, 'External Trade Law and the Constitutional Treaty: Towards a federal and more democratic common Commercial Policy?' (2005) 42 CMLR 102-103.

7 Due to the various meanings given in the literature to the terms "external" and "internal" with regard to Community competence, these terms are used in this article in order to define whether the scope of Community action extends to relations with third countries and their nationals. In order to distinguish between the types of action taken, namely between secondary Community legislation and international agreements or other international law instruments, the terms "autonomous measures" and "international agreements" are used respectively.

8 An analysis of the effects of the Lisbon Treaty on the orientation and future implementation of the Common Commercial Policy goes beyond the scope of this article and will only be complementarily addressed. 
the changes to the scope of EU competence in the field of the Common Commercial Policy is firstly provided, highlighting the completion and simplification of EU powers in the areas of trade in services and commercial aspects of intellectual property and the ambiguities arising from the inclusion of foreign direct investment within the scope of EU competence. Secondly, the article examines the effects of the Lisbon Treaty on the exclusive nature of EU competence, in particular in light of the need for parallelism between external and internal Community powers. Finally, the amendments of decision-making rules are scrutinised, looking in particular at whether and to what extent they satisfy the principles of effectiveness, simplification and legitimacy that triggered the reform of the Common Commercial Policy.

\section{The scope of EU competence}

The scope of EU competence in the field of the Common Commercial Policy is affected significantly by the Lisbon Treaty. Article 207 TFEU expands the scope of the Common Commercial Policy, while providing a clearer wording with regard to Community competences already existing under the current regime. It attempts to provide a more balanced approach with regard to the relationship between internal and external competences, and a single legal basis for the adoption of all measures that are necessary for the operation and implementation of the Common Commercial Policy.

\section{a) EU competence in areas of trade in services and commercial aspects of intellectual property}

The first significant change brought by the Lisbon Treaty is that it introduces clear rules with regard to the scope of Community competence in the areas of trade in services and commercial aspects of intellectual property (hereinafter IP), which has been one of the most controversial and ambiguous fields of EU external competence. Since the creation of the WTO, which established international rules on trade in services and trade-related IP rights, the EC has struggled to determine its scope of competence in these areas and delimitate it from Member States' powers. The existence of the EC's exclusive competence to conclude the GATS ${ }^{9}$ and TRIPS ${ }^{10}$ agreements was the focus of the benchmark decision of the Court of Justice in Opinion $1 / 94^{11}$ and later on, as a reaction to the strict interpretation of Article 133 TEC, of the Amsterdam and Nice Treaties.

\footnotetext{
9 General Agreement on Trade in Services [1994] OJ L336/190.

10 Agreement on Trade Related Aspects of Intellectual Property Rights [1994] OJ L336/213.

11 Opinion 1/94 WTO [1994] ECR I-5267.
} 
i) The emergence of EU competence in areas of trade in services and commercial aspects of intellectual property

In Opinion 1/94, the Court took the stance that Article 133 TEC, as it stood at the time, did not grant exclusive competence to the EC to conclude the GATS and TRIPS Agreements. With regard to GATS, the Court pointed out that the EC Treaty includes specific chapters on the free movement of persons, emphasising in essence the structural differences between the four freedoms in the internal sphere and their reflection in external relations. ${ }^{12}$ With regard to TRIPS, the Court opined that the majority of TRIPS provisions were outside the scope of the Common Commercial Policy, as their primary purpose was not the regulation of trade but the harmonisation of IP rights protection. The Court's Opinion has been heavily criticised, ${ }^{13}$ as it demonstrated the Court's reluctance to extend the notion of international trade beyond goods to services and establishment, signalling that the Common Commercial Policy could not be expanded to the Common Economic Policy but that it should be balanced with the internal competence in the field of services, establishment and IP regulation. ${ }^{14}$

Following Opinion 1/94 and its unclear delineation of competence, the IGC in Nice expanded the scope of the Common Commercial Policy to trade in services and trade-related aspects of IP, creating, however, a complex system of rules. The Nice Treaty kept intact paragraphs 1-4 of Article 133 TEC relating to trade in goods. By adding paragraphs 5-7 to Article 133 TEC, it brought issues relating to the provision of services, establishment and IP protection under the auspices of the Common Commercial Policy, though providing numerous exceptions to the scope of EC competence. The lack of clarity concerning the concepts of "trade in services" and "commercial aspects of intellectual property", the establishment of shared and joined competence in paragraph 6 for only some services, and the explicit reference to international agreements, which implies that the adoption of autonomous measures in these areas is excluded, are only some of the criticisms levelled against the amendments introduced in Nice. ${ }^{15}$

\footnotetext{
12 P Eeckhout, External Relations of the European Union: legal and constitutional foundations (OUP, Oxford, New York 2004) 29.

13 For a critical analysis of Opinion $1 / 94$ see $\mathrm{J}$ Bourgeois, 'The EC in the WTO and Advisory Opinion 1/94: An Echternach Procession' (1995) 32 CML Rev 763; Hilf, 'The ECJ's Opinion $1 / 94$ on the WTO, No Surprise but Wise?' (1995) 6 EJIL 245; T Tridimas, 'The WTO and OECD Opinions' in Dashwood and Hillion (eds), The general law of E.C. external relations (Sweet \& Maxwell, London 2000) 48; P Koutrakos, EU International Relations Law (Hart, Oxford, Portland 2006) 46-48.

14 Eeckhout (n 12) 57; Koutrakos (n 13) 47.

15 M Cremona, 'A Policy of Bits and Pieces? The Common Commercial Policy after Nice' (2001) 4 CYELS 69; C Hermann, 'Common Commercial Policy after Nice: Sisyphus would have done a better job' (2002) 39 CMLR 26.
} 
ii) Assimilating trade in services and commercial aspects of intellectual property with trade in goods

Addressing these criticisms, the Lisbon Treaty introduces new wording with regard to EU competence on trade in services and IP, enhancing clarity and preciseness. A first striking difference to Article 133 TEC is that the Lisbon Treaty ends the distinction between trade in goods and trade in services and commercial aspects of IP. Articles 133(1) and 133(5)(1) TEC are "merged", so that trade in services and commercial aspects of IP are no longer a different category from trade in goods. Paragraph 1 of Article 207 TFEU clearly stipulates that:

The common commercial policy shall be based on uniform principles, particularly with regard to changes in tariff rates, the conclusion of tariff and trade agreements relating to trade in goods and services, and the commercial aspects of intellectual property, foreign direct investment, the achievement of uniformity in measures of liberalisation, export policy and measures to protect trade such as those to be taken in the event of dumping or subsidies. (emphasis added)

Even though the assimilation of goods, services and commercial aspects of IP does not add to the current competence of the EC under Article 133 TEC, it is obvious that their common reference in Article 207(1) TFEU simplifies the delimitation of Union competence.

It is also remarkable that the Lisbon Treaty incorporates social, health, education and cultural services into the general scope of EU competence under Article 207(1) TFEU. The confusing reference to shared competence in Article 133(6)(2) TEC has been abandoned, ${ }^{16}$ so that all services sectors fall under the general scope of EU competence. However, the elimination of Article 133(6)(2) TEC does not necessarily mean that the same rules also apply with regard to these services. ${ }^{17}$ Article 207(4) TFEU provides special decision-making rules concerning these services sectors and the general limitation established in Article 207(6) TFEU suggests that the external aspects of the regulation of these services sectors do not fall entirely within the scope of Union competence. However, in any case, the elimination of Article 133(6)(2) TEC adds to the simplification of the Common Commercial Policy.

In addition, Article 207 TFEU grants the possibility of concluding international agreements and also adopting autonomous measures with re-

\footnotetext{
16 The second subparagraph of Article 133(6) TEC makes an explicit reference to "shared competence" with regard to employment, health, education and cultural services, which arguably establishes a priori shared competence between the Community and Member States. Cremona (n 15) 73-74; HG Krenzler and C Pitschas, 'Progress or Stagnation? The Common Commercial Policy After Nice' (2001) 6 EFA Rev 308-309.

17 See below section 2.c.
} 
gard to trade in services and commercial aspects of IP. Contrary to Article 133 TEC, which stipulates that the EC enjoys competence only to negotiate and conclude international agreements, ${ }^{18}$ the Lisbon Treaty enables the EU to adopt autonomous measures with regard to all aspects of the Common Commercial Policy and not only trade in goods. As Article 207(1) TFEU does not distinguish between goods, services and commercial aspects of IP, Article 207(2) TFEU, which stipulates that the relevant Union institutions are vested with the power 'to adopt measures defining the framework for implementing the Common Commercial Policy', applies to all aspects of the Common Commercial Policy. Similar to current Article 133(2) TEC, this provision should be read as enabling the Union to adopt autonomous measures, both in the form of substantive rules and rules necessary for the implementation of international agreements. ${ }^{19}$ The addition of the words 'defining the framework' in the Lisbon Treaty does not imply that the Union is only competent to define the general framework for achieving its policy goals. On the contrary, it grants the flexibility to the relevant institutions to decide the best means for implementing their policy goals. Consequently, the Lisbon Treaty puts an end to the need to use different legal bases having different institutional and decision-making rules to adopt autonomous measures with regard to trade in services and commercial aspects of IP.

iii) Defining "trade in services" and "commercial aspects of intellectual property"

Concerning the definition of trade in services and commercial aspects of IP, the Lisbon Treaty regrettably does not provide a definition of these terms. With regard to trade in services, the Lisbon Treaty remains silent on the debate whether this term is limited to services, as they are defined under the relevant EC Treaty chapter, or whether it reflects the similar term found in the WTO Agreements, thus covering all four different modes of supply of services provided in GATS, namely cross-frontier supply of services, consumption abroad and, more importantly, commercial presence and movement of natural persons related to the supply of services. ${ }^{20}$

During the negotiations at the European Convention, it became obvious that the term should be used by reference to GATS, including all

\footnotetext{
18 Cremona (n 15) 83.

19 Krajewksi (n 6) 107; J Ceyssens, 'Towards a common foreign investment policy? Đ Foreign investment in the European constitution' (2005) 32 LIEI 276.

20 In favour of a wide interpretation of the term, see Cremona (n 15) 69-70. In favour of a narrow interpretation excluding commercial presence and movement of natural persons from its scope, see S Griller and B Weidel, External Economic Relations and Foreign Policy in the European Union (Springer, Vienna 2002) 91-93.
} 
modes for the supply of services, hence including establishment in services sectors and movement of natural persons related to the supply of services. ${ }^{21}$ In favour of a broad interpretation of the term, there is also the fact that commercial presence is at the core of the new competence over foreign direct investment, which concerns the establishment of foreign investors in all economic sectors, thus in services sectors as well. Consequently, the debate on the definition of trade in services and whether it covers movement of persons seems to have been rendered defunct.

At this point, it should be noted that the Lisbon Treaty not only affirms the currently predominant perception that trade in services should be interpreted by reference to GATS, but it also does away with the current fragmentation of the competence rules concerning the establishment of non-EU nationals in the EU and of EU nationals in third countries. Even though EC competence in the area of trade in services indicates that the Common Commercial Policy has been extended to two other important areas of the internal market, namely establishment and provision of services, it does not mean that the Common Commercial Policy reflects the scope of Community powers in the internal field. So far only the power to regulate the establishment of persons trading in services has been transferred to the Community, which means that the establishment of persons whose business activities do not involve trade is excluded from the scope of the Common Commercial Policy. ${ }^{22}$ This distinction between establishment in the services and non-services sectors, which does not exist in the internal market, is abolished by the Lisbon Treaty, which adds foreign direct investment to the scope of the Common Commercial Policy, hence covering the establishment of foreign investors in all economic sectors. ${ }^{23}$

In contrast with trade in services, ambiguity seems to continue with regard to the definition of commercial aspects of IP. Even though it is widely accepted that the term should be interpreted by reference to the WTO and the TRIPS Agreement, the debate whether the term reflects TRIPS as it stood at the time of the conclusion of the Treaty or as it will evolve remains open. ${ }^{24}$ The choice between a "static" or a "dynamic" definition of commercial aspects of IP becomes more crucial under the Lisbon Treaty, since a provision similar to Article 133(7) TEC, which grants the possibility to the Council to extend the scope of paragraphs 1-4 of Article 133 TEC to the negotiation and conclusion of international agreements on IP in general, is not included in the new text. Therefore, in contrast with

21 Krajewksi (n 6) 110-111; Cremona (n 3) 30.

22 Ceyssens (n 19) 260.

23 See also below section 2.b.

24 Hermann (n 15) 18-19; Cremona (n 15) 71-72 and Koutrakos (n 13) 63 are in favour of a "static" interpretation, while Krenzler and Pitschas (n 16) 302 are in favour of a "dynamic" interpretation of the term. 
the static interpretation of the term preferred in light of Article 133 TEC, it now seems that leaving regulation of IP as a whole outside the scope of the Common Commercial Policy indicates that a dynamic interpretation of commercial aspects of IP should be adopted. ${ }^{25} \mathrm{~A}$ basic objective of the reform of the Common Commercial Policy was to grant competence to the Union to participate in the WTO and negotiate future amendments to WTO Agreements. Hence, the lack of a provision similar to Article 133(7) TEC probably indicates that commercial aspects of IP are not strictly connected to the current TRIPS Agreement, but cover all issues that may be included in the TRIPS Agreement after a future WTO round.

The simplification and clarification of EU competence over trade in services and commercial aspects of IP presents a huge step towards a complete legal framework for external economic affairs. The Lisbon Treaty significantly enhances the link between EU competence and the WTO, allowing the EU to follow and actively participate in international developments and advance its position both internally and externally. Furthermore, the assimilation of goods, services and IP suggests that the Common Commercial Policy reflects to a large extent the internal market, where free movement of goods, services and establishment are of equal legal value. Also taking into account the addition of foreign direct investment to the scope of EU powers, the Common Commercial Policy seems to be departing from its "traditional" trade core and is becoming the basic tool not only for serving the external needs of the internal market but also for building an autonomous EU external economic policy.

\section{b) EU competence in the area of Foreign Direct Investment}

The Lisbon Treaty establishes for the first time an express competence over foreign investment by including it in the scope of the Common Commercial Policy. Even though the debate over the inclusion of Foreign Direct Investment (FDI) generated great controversy and criticism, ${ }^{26}$ the Lisbon Treaty, following the text of the Constitutional Treaty, extended the Common Commercial Policy to the second most important field of international economic relations, namely foreign investment. The express inclusion of FDI under the Common Commercial Policy is of the utmost importance, as it empowers the Union to take external action with respect to most aspects of foreign investment regulation and facilitates the exercise of its current, fragmented and incomplete competence over foreign investment by establishing a single legal basis. However, the inclu-

\footnotetext{
25 Ceyssens (n 19) 260.

26 There were many suggestions at the European Convention which advocated that foreign investment should not be included within the scope of the Common Commercial Policy. See Krajewski (n 6) 104.
} 
sion of FDI as part of the Common Commercial Policy does not mean that the EU can take action under the new provision with regard to all matters concerning foreign investment regulation. In order to delimitate the scope of EU competence, it is necessary to examine firstly the categories of foreign investment and secondly the aspects of foreign investment regulation that are covered in Article 207 TFEU.

\section{i) Defining Foreign Direct Investment}

It is apparent from the wording of Articles 206 and 207 TFEU that the new competence is limited only to foreign direct investment. Even though there is no further clarification of the term in the Treaty, the concept of FDI should be interpreted by reference to the Community rules on direct investment and, most importantly, in accordance with the notion of FDI in international law. Similar to the concept of trade in services, the international law definition of FDI is more important for defining FDI within the scope of the Common Commercial Policy. In Community law, the term direct investment is used in Article 57(2) TEC as well as in the capital directive. ${ }^{27} \mathrm{FDI}$ is associated with establishment or participation in new or existing undertakings via equity or security holdings which are characterised by the existence of a lasting link and managerial control of their activity as well as with long-term loans. ${ }^{28}$ The concept of direct investment in Community law corresponds to the concept of direct investment in international law, ${ }^{29}$ which emphasises duration and managerial control as the main elements of FDI. The common determination of FDI in both Community and international law facilitates the interpretation of Articles 206 and 207 TFEU, which establish competence only with regard to foreign direct investments. ${ }^{30}$

As a result, portfolio investments, as well as other categories of foreign investment, for example IP rights, money claims and concession contracts, are excluded from the scope of the new competence. ${ }^{31}$ This exclusion does

\footnotetext{
${ }_{27}$ Council Directive [EEC] 88/361 of 24 June 1988 for the implementation of Article 67 of the Treaty (1988) OJ L 178/5.

28 For example see Commission v Spain [2003] ECR I-4581, para 53 and J Handoll, Capital, Payments and Money Laundering in the European Union (Richmond, Richmond 2006) 27-28.

29 For an analysis of the definition of investment in international investment law see N Rubins, 'The Notion of Investment in International Investment Arbitration' in Horn (ed) Arbitrating Foreign Investment Disputes (Kluwer, 2004) 284 ; F Yala, 'The Notion of Investment in ICSID Case Law: A Drifting Jurisdictional Requirement?' (2005) 22 Journal of International Arbitration 105.

30 Ceyssens (n 19) 274; Krajewski (n 6) 112; J Karl, 'The Competence for Foreign Direct Investment' (2003) 4 JWI\&T 420.

31 The term foreign investment is used in international investment agreements very broadly so that it covers not only foreign direct investment but also any assets of an economic value as long as certain criteria are fulfilled.
} 
not mean that the EU will not enjoy competence to take external action with regard to these categories of foreign investment. The express recognition of competence over FDI does not negate EU powers which are conferred on it by virtue of other Treaty provisions. On the contrary, the EU will remain competent to the extent that the current Treaty empowers the Community to regulate these categories of foreign investment.

\section{ii) The scope of Community competence over foreign investment in the EC} Treaty

In order to assess the importance of the inclusion of FDI in the Common Commercial Policy, it is necessary to examine briefly whether and to what extent the different aspects of foreign investment regulation currently fall within EC competence. A brief overview of the fragmented, incomplete and complex system of Treaty rules enabling the Community to take external action on foreign investment illustrates the need for establishing an explicit legal basis for foreign investment and provides the necessary background for scrutinising the controversial aspects of the new FDI competence.

In a nutshell, foreign investment regulation touches upon diverse regulatory interests, as it mainly concerns the admission of foreign investment, its treatment and the protection of foreign investment against expropriation. ${ }^{32}$ Within this patchwork of distinct regulatory concerns, the EC has placed greater emphasis on admission of foreign investment. Aiming at liberalisation and market access, which have been the main tools used for economic integration in the internal market, the EC Treaty empowers the Community to take external action concerning the admission of foreign investment. Nevertheless, a specific legal basis has been missing so far and different Treaty provisions are used in order to cover this gap without always providing clear powers to the Community. ${ }^{33} \mathrm{Ar}$ ticle 56 TEC provides for the liberalisation of capital movements to and from third countries, including capital movements related to foreign investment. However, the concept of capital movement and the relation of Article 56 TEC to the Treaty provisions on establishment probably indicate that its scope is limited only to the actual transfer of assets

\footnotetext{
32 Originally the main subject of foreign investment regulation concerned the protection of foreign investors' property from expropriation and the guarantee of a minimum standard of treatment. Over time, international foreign investment regulation has been expanded to standards of treatment of foreign investors and specific issues important for foreign investors such as performance requirements. Admission of foreign investment has been traditionally kept under national control but it has been incorporated gradually into international investment agreements.

33 For a brief overview of EC competence over foreign investment see Ceyssens (n 19) 260-262; W Shan, 'Towards a common European community policy on investment issues' (2001) 2 JWI\&T 607-610.
} 
destined to be used for the establishment of an investor and not to the conditions of initial establishment as such. ${ }^{34}$ The initial establishment of foreign investors is covered partially by Article 133 TEC, as long as it is accepted that trade in services covers the commercial presence of foreign investors. Nevertheless, this provision is limited only to investments in services sectors. Complementing Article 133 TEC, the Treaty rules on establishment can arguably be considered to confer implied powers on the Community with regard to the initial establishment of foreign investors in all economic sectors. However, in accordance with the doctrine of implied powers, the existence of such implied powers requires that regulation of the activity of third country nationals in the EU as well as of EU nationals in third countries is necessary for the attainment of the objectives of the internal market, which is not always clear. Furthermore, such competence is shared with Member States and exclusivity arises only if the criteria of AETR-type exclusivity are fulfilled. Similar concerns exist with regard to the post-establishment treatment of foreign investors, where again the foundations of EC competence are rather obscure. ${ }^{35}$

Protection of foreign investment against expropriation is the most widely disputed field of foreign investment regulation in terms of EC competence. Firstly, it is unclear whether expropriation of foreign investment is excluded from Community law interference by virtue of Article 295 TEC, which safeguards the property ownership systems of Member States. Furthermore, it is also controversial whether the Community has the power to take positive action and determine the conditions under which expropriation of foreign investors' property is legal and whether and to what extent the foreign investor is entitled to compensation. As a result, protection of foreign investment against expropriation has so far been completely excluded from Community agreements dealing with foreign investment, and this field has been widely considered to fall within the exclusive competence of Member States.

iii) The scope of Union competence to regulate foreign investment under the Lisbon Treaty

The inclusion of FDI within the scope of the Common Commercial Policy provides a first significant step towards reassessing the delimita-

\footnotetext{
34 For an analysis of the relevance of Article 56 TEC for foreign investment regulation see R Torrent, 'Derecho comunitario e Inversiones extranjeras directas: Libre circulacion de los capitales vs. Regulacion no discriminatoria del establecimiento. De la golden share a los nuevos Open Skies' (2007) 22 Revista Espanola de derecho europeo 291.

35 The existence of implied powers with regard to the establishment of foreign investors has been indirectly recognised in Opinion 2/92 ([1995] ECR I-521), where the Court held that the Community enjoyed competence, albeit non-exclusive, to conclude the OECD National Treatment Instrument. For an analysis of the Opinion see Tridimas (n 13).
} 
tion of competence between the Union and Member States by simplifying the current complex system of rules, solidifying Union competence with regard to certain aspects of foreign investment regulation and offering a framework for establishing a common foreign investment policy. However, it is unclear whether Article 207 TFEU confers power on the Union to take action concerning all aspects of FDI regulation.

Firstly, issues of admission of foreign investment fall within the scope of FDI competence. ${ }^{36}$ Its placement under the Common Commercial Policy, which is based on principles of uniformity and liberalisation, reveals that FDI competence is primarily concerned with market access, hence allowing the EU to take action with regard to the initial establishment of foreign investors. However, FDI competence partially overlaps with Union competence concerning trade in services, which covers establishment in services sectors. Even though as a matter of principle FDI competence should be considered as embracing establishment in all economic sectors, thus uniting rules on establishment, the distinction between FDI and trade in services is of minor practical significance, as they are both part of the Common Commercial Policy and are subject to identical rules.

In contrast with initial establishment, it is unclear whether FDI competence encompasses capital movements relating to FDI. Article 63 TFEU (ex 56 TEC) refers explicitly to capital movements to and from third countries, while Articles 64-66 TFEU (ex 57-59 TEC) establish specific rules concerning limitations on capital movements to and from third countries. It can be argued that the mere fact that measures adopted under the Common Commercial Policy have repercussions on certain economic sectors falling under other Treaty chapters does not constitute a reason to exclude them from the scope of the Common Commercial Policy. ${ }^{37}$ However, this is not necessarily the case for investment-related capital movements. International investment agreements not only have effects on capital movements, but also aim, among other things, to provide a framework for their liberalisation. On the other hand, Article 63 TFEU does not explicitly provide for the conclusion of international agreements, while Article 207 TFEU predominantly concerns EU action in the international sphere.

It is also unclear whether FDI competence includes all aspects of post-establishment treatment of foreign investors. Article 49 TFEU (ex 43 TEC) remains the basic provision concerning treatment of EU companies regardless of their ownership or control. ${ }^{38}$ However, Article 207

\footnotetext{
36 Ceyssens (n 19) 276-277; Krajewski (n 6) 114; Karl (n 30) 421.

37 Opinion 1/78 [1979] ECR 2871 para 49; Ceyssens (n 19) 284.

38 Article 54 TFEU grants EU nationality to all firms having their registered office, central administration or principal place of business in the EU, regardless of whether they are owned or controlled by foreign nationals. Hence, Article 54 TFEU obliges the EU to treat foreign investors established in its territory as EU nationals.
} 
TFEU has a much broader scope, as it confers powers with regard to all foreign established persons, irrespective of whether they fulfil the criteria of Article 54 TFEU (ex 48 TEC). Moreover, FDI competence is broader so as to explicitly include all standards of treatment of FDI, in particular Fair and Equitable Treatment (FET), ${ }^{39}$ and to cover the treatment of EU controlled or managed undertakings in third countries which do not fall straightforwardly within the scope of Union competence by virtue of establishment rules.

Furthermore, the scope of FDI competence extends to specific aspects of foreign investment regulation, such as performance requirements and the movement of key personnel. Many of these issues are already covered by Community/Union competence, for example trade-related performance requirements and movement of persons related to the supply of services. ${ }^{40}$ Article 207 TFEU expands Union competence with regard to most other performance requirements and movement of investmentrelated key personnel. However, in this field the limitation established in paragraph 6 of Article 207 TFEU becomes apparent. This preserves Member States' powers in fields which are excluded entirely from Union interference or from harmonisation by means of Union legislation. For example, the EU cannot use its FDI competence to regulate issues falling outside the scope of its powers and nor can it use its competence to harmonise areas of law where harmonisation is ruled out, such as public health, cultural or social services. ${ }^{41}$

It is also noteworthy that FDI competence will provide a specific legal basis allowing for the inclusion of investor-state dispute settlement provisions in future Union agreements and for the conclusion of international agreements concerning investor-state dispute settlement, such as the ICSID Convention. ${ }^{42}$ However, dispute settlement mechanisms adopted in

\footnotetext{
39 Ceyssens (n 19) argues that FET is excluded from the scope of new FDI competence. Basing his argument on parallelism, he asserts that FET is not regulated in the internal market, and therefore it cannot be regulated in external relations. However, this argument does not take into account the fact that the lack of exercise of internal powers does not preclude in the framework of the Common Commercial Policy the exercise of external competence.

40 Trade-related performance requirements, such as import and export quotas, the use of local goods or services and the regulation of production rates are issues that are regulated in the TRIMs Agreement. The TRIMs Agreement is part of the WTO Multilateral Agreement on Trade in Goods, concerning which the Court manifestly declared in Opinion 1/94 (n 11 para 34) that the Community is exclusively competent to conclude. For the movement of persons related to the supply of services see above in section 2.a.iii.

41 For the precise scope of the limitation set out in Article 207(6) TFEU see below in section 2.c.

42 The question of EU competence to accede to the ICSID Convention is different from the question concerning the eligibility of the $\mathrm{EC}$ as a supranational organisation to accede to it as a matter of international law. As Article 67 of the ICSID Convention allows only States to accede to it, the Convention should be amended in order for the EU to become a contracting party.
} 
Union agreements must conform to the jurisdictional limits set by Opinions $1 / 91^{43}$ and $1 / 2003^{44}$ so that the jurisdiction of the Court of Justice is respected.

Finally, it is debatable whether Article 207 TFEU will bring protection of foreign investors against expropriation within EU competence, thus covering the most important aspect of foreign investment regulation which remains so far entirely outside the scope of Community regulation. The exclusion of investment protection from the scope of the Common Commercial Policy is strongly advocated, based on the trade character of the Common Commercial Policy and the exclusion of investment protection from the scope of internal Union powers. With regard to the trade orientation of the Common Commercial Policy, it is argued that Article 207 TFEU cannot extend to measures of investment protection, as this goes beyond the "traditional" character of the Common Commercial Policy which concerns market access and the abolition of restrictions, hence covering only issues of establishment and post-establishment treatment. ${ }^{45}$ Article 206 TFEU provides that "the Union shall contribute, in the common interest, to the harmonious development of world trade, the progressive abolition of restrictions on international trade and on foreign direct investment, and the lowering of customs and other barriers" (emphasis added), thus not including FDI protection within its scope. However, this argument does not take into consideration the fact that the Common Commercial Policy has been expanded beyond trade, not only by the inclusion of foreign investment, but also by the inclusion of commercial aspects of IP that are mainly related to property protection and restrictions rather than liberalisation. In this regard, the notion of restrictions on FDI mentioned in Article 206 TFEU can be interpreted as including property protection restrictions, similar to the property protection restrictions abolished by TRIPS. The fact that Article 207 TFEU does not distinguish between trade in goods and other aspects of the Common Commercial Policy, as Article 133 TEC does, illustrates that the Lisbon Treaty is moving further away from the traditional trade orientation of the Common Commercial Policy, which is expanding towards other fields of economic activity. ${ }^{46}$

In addition, it is reasonable to exclude protection against expropriation from the scope of the new FDI competence if Article 345 TFEU (ex 295 TEC) is interpreted as safeguarding Member States' powers with regard to the entirety of the issues affecting their property regime. Moreo-

\footnotetext{
43 Opinion 1/91 [1991] ECR I-6079.

44 Opinion 1/2003 [2006] ECR I-1.

45 Krajewski (n 6) 114.

46 Ceyssens (n 19) 278-279; Karl (n 30) 421.
} 
ver, if internal harmonisation of rules on expropriation is excluded from the scope of Articles 114, 115 and 352 TFEU (ex 95, 94 and 308 TEC), it is again obvious that the principle of parallelism affirmed in paragraph 6 of Article 207 TFEU excludes investment protection from the scope of the Common Commercial Policy.

With regard to Article 345 TFEU, it is arguable that it does not preserve exclusive powers for Member States to determine expropriation. Article 345 TFEU has been interpreted narrowly so that its scope concerns only the right of Member States to nationalise private property or to privatise public property. ${ }^{47}$ It reserves for Member States only the power to decide whether and when expropriation occurs and not the conditions under which such expropriation takes place. The latter, which is the subject of foreign investment regulation, does not fall under the scope of $\mathrm{Ar}$ ticle 345 TFEU. ${ }^{48}$ On the contrary, it is arguable the EU has the right to determine the conditions of indirect expropriation of foreign investment resulting from Union measures ${ }^{49}$ while it can also harmonise national laws on conditions of expropriation resulting from national measures. The power to harmonise rules on the exercise of property rights has already been used in the field of IP rights and it can be considered in many instances necessary for the attainment of the objectives of the internal market. Even though the internal power for harmonisation has not been used so far, this does not imply that external competence does not exist, as this would negate the foundations of the principle of parallelism which determines the scope of EU external competence. ${ }^{50}$

As a result of the inclusion of FDI within the scope of the Common Commercial Policy, the Lisbon Treaty has taken a huge step towards establishing the Common Commercial Policy as the basic tool of external economic action. Movement of persons between the Union and third countries, with the exception of labour movement, which is dealt with in the Treaty chapter on Justice, Security and Home Affairs, becomes part of the scope of the Common Commercial Policy, thus completing paral-

\footnotetext{
47 For example in Costa $v$ ENEL (Case 6/64 [1964] ECR 1251) and in Fearon (Case 182/83 [1984] ECR 3677) the Court clearly stated that Article 295 TEC does not preclude the application of community rules in the field of property expropriation. The narrow scope of Article 295 TEC has also been firmly recognised in the field of IP, where the Court found that regulation of IP rights concerning not only their exercise but also their existence can be adopted at Community level.

48 C Von Milczewski, Der grundrechtliche Schutz des Eigentums im Europäischen Gemeinschaftsrecht (Peter Lang Frankfurt, New York 1994) 23-30.

49 The Court has recognised in Nold'Case 4/73 [1974] ECR 491) and in Bosphorus (Case C-84/95 [1996] ECR I-3953) that there are general principles of Community law that safeguard property rights and determine the conditions under which these rights can be limited by Community law.

50 Cf Ceyssens (n 19) 281.
} 
lelism between internal and external powers as far as the existence of EU competence is concerned.

Furthermore, it is noteworthy that Article 207 TFEU vests the Union with significant powers in the field of foreign investment and enables it to substitute Member States in the international sphere. Given, however, the plethora of contractual commitments undertaken so far by Member States, which have concluded more than 1,000 Bilateral Investment Treaties with third countries, it is still unclear whether, when and how the Union will exercise its new powers. The lack of clarity concerning the substantive scope of FDI competence in conjunction with the legislative changes required, in particular with regard to investment protection, adds to the speculation concerning the willingness of Member States to accept the transfer of their powers to the EU and future challenges by them to EU action in this field.

\section{c) Limitations of Union competence}

The expansion of the Common Commercial Policy to trade in services, FDI and commercial aspects of IP has rendered necessary the establishment of an explicit link between the internal market and external action. The need to avoid the paradox of an external competence superseding internal powers was expressed in Article 133(6) TEC which parallelises internal and external powers and curbs Community competence with regard to certain services sectors. After the Lisbon Treaty, the need for parallelism between internal and external action has become greater than before, as FDI has been included within the scope of Union competence and Article 207 TFEU does not distinguish between goods, services, FDI and commercial aspects of IP. Hence, similar to the current Article 133 TEC, the Lisbon Treaty provides in Article 207(6) TFEU for limitations upon Union competence in the field of the Common Commercial Policy based on the principle of parallelism.

However, the Lisbon Treaty adopts a different approach towards parallelism. In the first sentence of paragraph 6 of Article 207 TFEU, a general parallelism clause is established so that 'The exercise of the competences conferred by this Article in the field of the Common Commercial Policy shall not affect the delimitation of competences between the Union and the Member States'. The second sentence of the same paragraph provides a limitation on the content of measures that can be taken under Article 207 TFEU so that the exercise of Union competences 'shall not lead to harmonization of legislative or regulatory provisions of the Member States insofar as the Treaties exclude such harmonization'.

Starting with the second sentence of Article 207(6) TFEU, the wording resembles to a great extent the limitation of EC competence found in Article 133(6) TEC. The exercise of Union powers is limited in fields where 
harmonisation is excluded by the Treaty, which means that the Common Commercial Policy cannot be used for the adoption of Union measures in fields in which other Treaty provisions allow only limited Union interference. ${ }^{51}$ However, this provision should not be broadly interpreted as requiring full harmonisation in a specific field. As has already been convincingly argued under the EC Treaty, ${ }^{52}$ the text is clear that only areas where harmonisation is excluded fall outside the scope of the Common Commercial Policy, which means that it includes areas of law where the EC Treaty provides for minimum harmonisation.

This specific limitation of Union competence is part of the broader parallelism principle which is established in the first sentence of paragraph 6. Article 207(6)(a) TFEU establishes explicit parallelism between internal and external EU competences in the sense that external powers cannot be used to override the limits of internal Union competence with regard to the same subject matter. ${ }^{53}$ Consequently, when the Union exercises its powers under the Common Commercial Policy, it is subject to the same limitations on its competence that exist in the internal market with regard to the same subject matter. However, this does not mean that the lack of exercise of Union internal competences poses a limitation on the existence or the exercise of external competence. It is remarkable that the requirement of unanimity for the adoption of commercial policy measures in cases where no internal measures have been adopted, has not been incorporated in Article 207(4) TFEU, thus proving that a lack of internal rules is no impediment to the adoption of external action even at the procedural level. ${ }^{54}$ As a result, the Union can take action in all areas of the Common Commercial Policy to the extent that it is competent to legislate in this area of the internal market, even if it has not acted so far, for example in the field of property expropriation. ${ }^{55}$

Taking into account the negotiating history of the Constitutional Treaty and the fact that the limitation of paragraph 6 applies to all areas of the Common Commercial Policy and to both the adoption of autonomous measures and the negotiation and conclusion of international agreements, it is argued that this limitation refers only to internal implementing powers and not to the competence to negotiate and conclude

\footnotetext{
51 Ceyssens (n 19) 280; Krajewski (n 6) 115.

52 Hermann (n 15) 22.

53 As Ceyssens rightly argues, a literal understanding of the first sentence makes little sense, since the Common Commercial Policy concerns economic activities which are not covered by the internal market provisions, as the latter are limited to EU nationals or intracommunity movement of goods.

54 See below section 4.a.

55 See above section 2.biii.
} 
international agreements. ${ }^{56}$ Drawing a parallel with federal states, which have the power to conclude international agreements on issues that are internally beyond the scope of their federal legislative competence, it was argued that the Constitutional Treaty brought a similar change to the scope of EU external powers in the field of the Common Commercial Policy. However, this position does not take into account the fact that in the new Treaty as well as in the Constitutional Treaty EU powers are based on the principle of attribution, ${ }^{57}$ so that the Union has only the competences conferred on it by Member States. The principle of parallelism constitutes one of the cornerstones of external competence, especially in the field of implied powers, so that its complete negation in the field of Common Commercial Policy would diminish its value. In addition, the EU is far from becoming a federal state where external powers are exclusively exercised at the "federal" level.

Finally, it should be mentioned that the Lisbon Treaty retains the exclusion of transport services from the scope of the Common Commercial Policy. Following the reasoning of the Court in Opinion 1/94 that Community competence with regard to transport services is established only within the limits set in the respective Treaty chapter, ${ }^{58}$ the Lisbon Treaty provides in Article 207(5) TFEU that 'the negotiation and conclusion of international agreements in the field of transport shall be subject to Title V of Part Three and to Article 188 N'.

\section{The nature of Union competence in the field of the Common Commercial Policy}

\section{a) Exclusivity of Union competence}

The Lisbon Treaty impacts not only on the scope of EU competence in the field of the Common Commercial Policy, but also on the nature of EU competence. The importance of the nature of EU competence becomes easily apparent, considering that the majority of external competence cases relate to the question of whether EU competence in a given field is exclusive or shared with Member States, as it is only the recognition of exclusive competence that renders the EU the sole normative actor in a specific field. The Lisbon Treaty brings significant innovations

\footnotetext{
56 Krajewski (n 6) 116-117.

57 Article 5 TEU (ex 5 TEC) provides that ' 1 . The limits of Union competences are governed by the principle of conferral. The use of Union competences is governed by the principles of subsidiarity and proportionality. 2. Under the principle of conferral, the Union shall act only within the limits of the competences conferred upon it by the Member States in the Treaties to attain the objectives set out therein. Competences not conferred upon the Union in the Treaties remain with the Member States.'

$58 \mathrm{~N} 11$.
} 
with regard to the nature of EU competence in the field of the Common Commercial Policy, as it solidifies the exclusive nature of EU competence with regard to trade in goods and expands exclusivity beyond goods in all other areas of the Common Commercial Policy.

The recognition of the exclusivity of Community powers was one of the major characteristics of the Common Commercial Policy that enabled its development into one of the most important fields of EC action. At a time when the basic principles of EC external relations law, such as the doctrine of implied powers, ${ }^{59}$ were formulated by the Court of Justice, the Court found that Member States could not legislate in an area which would affect the operation of the Common Commercial Policy, even if the Community had not yet taken any action in the field. ${ }^{60}$ The a priori preemption of Member States' powers was justified by the internal market need for the existence of uniform rules and the need to preserve the unity of the Community's position with respect to third countries and to defend the "common interests" of the Community. ${ }^{61}$ Hence, even though the EC Treaty did not make any reference to exclusive powers in the field of the Common Commercial Policy, exclusivity was judicially recognised with regard to trade in goods based on internal market and external representation rationales.

Differentiating from the "traditional" Common Commercial Policy, the Nice Treaty established complex rules with regard to the nature of EC competence in the new areas of trade in services and commercial aspects of IP. Article 133(5)(4) TEC provides for shared competence in the area, grandfathering prior Member State agreements, and reaffirming their right to conclude new agreements in these areas. ${ }^{62}$ However, it is controversial whether, and to what extent, the principle of implied exclusivity ${ }^{63}$ applies in the field. ${ }^{64}$ It is unclear whether Community action in

59 Case 22/70 Commission v Council (AETR) [1971] ECR 263.

60 Opinion 1/75 [1975] ECR 1355.

61 For an analysis of the a priori exclusive character of Community competence in the field of the Common Commercial Policy see Koutrakos (n 13) 13-17.

62 Cremona (n 15) 84; Hermann (n 15) 19; Krenzler and Pitschas (n 16) 306.

63 Exclusivity of implied powers (AETR exclusivity) arises in circumstances where common rules have been adopted and exclusivity is necessary to avoid any effect on the common rules which may result from autonomous action taken by Member States. Implied exclusivity will arise in particular where there is complete harmonisation of a given area of law, where there exists internal legislation relating to treatment of nationals of non-Member States and finally where the power to negotiate with non-Member States has been conferred on Community institutions. See Opinion 1/94 (n 11) paras 76-78, 96 and Case C-467/98 Commission v Denmark [2002] ECR I-9519 paras 104-111 (Open Skies case). For an analysis of AETR type exclusivity see Koutrakos (n 13) 84-88, 110-112; Eeckhout (n 12) 59-64, 92-94.

64 Cremona (n 15) 86; Hermann (n 15) 19; cf Krenzler and Pitschas (n 16) 306; R Holdgaard, 'The European Community's Implied External Competence after the Open Skies Cases' (2003) 8 EFA Rev, 386. 
this specific field renders EC competence automatically exclusive, while in practice the need for concrete application of the exclusivity criteria for each services sector and IP protection norm renders the exact delimitation of Community exclusive competence practically unmanageable. Furthermore, the reference to joined competence in Article 133(6)(2) TEC, as has already been discussed, ${ }^{65}$ complicates the determination of the nature of EC competence in the field.

In sharp contrast with the existing regime, the Lisbon Treaty explicitly recognises that Union competence in the field of the Common Commercial Policy is exclusive. Given the assimilation of all areas of the Common Commercial Policy, it is strongly arguable that exclusivity covers not only trade in goods, but also trade in services, FDI and commercial aspects of IP. ${ }^{66}$

Article 3(1)e TFEU clearly stipulates that the Common Commercial Policy falls within the exclusive competence of the Union, while Article 2(1) TFEU integrates the principle that express powers are of an a priori exclusive nature. In contrast with the previous regime, exclusivity is not only relevant for the traditional scope of the Common Commercial Policy, but also includes trade in services, commercial-related aspects of IP and FDI. It is notable that Article 207 TFEU does not include a provision similar to Article 133(5)(4) TEC, which retained the right of Member States to maintain and conclude agreements with third countries. Article 207 TFEU does not distinguish between the different aspects of the Common Commercial Policy in terms of competence, nor does Article 3 TFEU limit its scope to trade in goods. In addition, the fact that there are exceptional rules concerning voting requirements for trade in services, commercial aspects of IP and FDI has no implications for the exclusive character of Union competence, which is by no means affected by the need for unanimity in decision-making.

In addition, the limitation set in paragraph 6 of Article 207 TFEU cannot be interpreted as carving out exclusivity in the areas where the Union does not have exclusive competence in the internal sphere. Paragraph 6 concerns the internal powers of Member States and establishes parallelism by excluding Union exclusive competence in the areas where the Union does not enjoy any competence internally. It cannot be interpreted as establishing shared competence with regard to all areas of the Common Commercial Policy that internally fall under shared competence. This would contradict the clear recognition of exclusivity in Article 2 TFEU as well as the long established recognition of exclusivity in the field of trade in goods. For example, exclusivity would not cover certain is-

65 See above section 2.ai.

66 Cremona (n 3) 30; Ceyssens (n 19) 286-287; Krajewski (n 6) 108-109. 
sues relating to trade in goods, such as quantitative restrictions. As they fall outside the scope of the customs union, but within the scope of the internal market, which is now expressly an area of shared competence, and since paragraph 6 does not distinguish between trade in goods and other aspects of the Common Commercial Policy, this would imply that aspects of external trade in goods are also an area of shared competence, subject only to AETR-type exclusivity.

\section{b) Breaking parallelism between internal and external powers?}

Even though the recognition of exclusive Union competence clarifies and solidifies EU powers in the field of the Common Commercial Policy, it presents the first significant deviation from the principle of parallelism between internal and external powers. In the internal market, exclusivity of Union powers arises only after their exercise, in accordance with the principles of subsidiarity and pre-emption. In this regard, the Lisbon Treaty appears to take a step back from the balance between internal and external powers that is currently safeguarded by the existence of shared competence over trade in services and commercial aspects of IP, which reflects the delimitation of competence in these areas in the framework of the internal market.

However, exclusivity of Union powers is necessary in external economic relations in order to enhance the simplification and effective application of the Common Commercial Policy. Advanced internal economic integration solidifies the existence of a single, common Community interest in all economic fields which is better served if the Union is the only actor in the international arena. In addition, the individual interests of Member States in sensitive sectors are not undermined, as they play a decisive role in formulating the Common Commercial Policy, especially in fields where unanimity is required for decision-making. ${ }^{67}$ The exclusive nature of Union competence does not imply that Member States can no longer pursue their policies in this field; on the contrary it affects only their means of action in the sense that Member States are obliged to act within the institutional framework of the Union, contributing to the formulation of the Common Commercial Policy.

Despite the lack of balance between internal and external powers, the exclusive character of Union competence in the field of the Common Commercial Policy should not be broadly interpreted as affecting the exercise of Member States' internal concurrent powers. Even though measures adopted under the Common Commercial Policy can potentially lead to internal harmonisation in a specific area, this does not mean that the EU is exclusively competent to regulate in this field. Exclusiv-

67 See below in section 4.a. 
ity under the Common Commercial Policy appears only in relations with third countries, in fields where the Union is vested with the power to take measures internally and to the extent that harmonisation achieved through the adoption of such measures is allowed.

\section{Decision-making procedures}

Until now, the adoption of decisions by the Council, excluding the Parliament from any interference with the exercising of Community powers, and the complex rules determining whether decisions should be adopted on the basis of qualified majority voting (QMV) or unanimity were the two basic characteristics of decision-making procedures in the field of the Common Commercial Policy ${ }^{68}$ The Lisbon Treaty introduces new provisions on decision-making of paramount importance. Adding to the simplification of the Common Commercial Policy, enhancing parallelism with regard to voting requirements and granting a significant role to the Parliament, the Lisbon Treaty brings legitimacy to the formation of the Common Commercial Policy and solidifies the effectiveness of its implementation.

Before discussing the innovative provisions on decision-making, it is worth noting that the Lisbon Treaty, following the current rules, recognises the significant role played by the Commission in the field of the Common Commercial Policy. The Commission is given the privilege of submitting proposals to the Council for the adoption of autonomous measures and to make recommendations for the negotiation and conclusion of an international agreement. ${ }^{69}$ The Commission is also entrusted with the task of carrying out negotiations with third countries, after a mandate to open negotiations is granted by the Council, and ensuring the compatibility of agreements negotiated under Article 207 TFEU with internal Community policies and rules. ${ }^{70}$

\footnotetext{
68 Koutrakos (n 13) 147-148; Cremona (n 15) 77-78

69 With regard to the adoption of autonomous measures, paragraph 2 of Article 207 TFEU refers to ordinary legislative procedure, according to which the initiation of legislative proposals belongs primarily to the Commission. With regard to the conclusion of international agreements, paragraph 3 of Article 207 TFEU explicitly provides that The Commission shall make recommendations to the Council, which shall authorise it to open the necessary negotiations. The Council and the Commission shall be responsible for ensuring that the agreements negotiated are compatible with internal Union policies and rules'.

70 Article 207(3)(3) TFEU provides that 'The Commission shall conduct these negotiations in consultation with a special committee appointed by the Council to assist the Commission in this task and within the framework of such directives as the Council may issue to it. The Commission shall report regularly to the special committee and to the European Parliament on the progress of negotiations'.
} 


\section{a) Voting requirements in the Council}

Similar to the current regime, QMV is the basic rule determining decision-making in the field of the Common Commercial Policy. Article 207 TFEU states in paragraph 2 that 'The European Parliament and the Council, acting by means of regulations in accordance with the ordinary legislative procedure, shall adopt the measures ...' (emphasis added) and in paragraph 4(1) that 'For the negotiation and conclusion of the agreements referred to in paragraph 3 , the Council shall act by a qualified majority'. Hence, it is clear that the adoption of internal measures and the negotiation and conclusion of international agreements are subject to qualified majority voting. These provisions establish a common regime for all aspects of the Common Commercial Policy without distinguishing between goods, services, FDI or commercial aspects of IP. In this regard, the Lisbon Treaty follows the pattern of merging the different aspects of the Common Commercial Policy at the procedural level as well.

As an exception to the QMV rule, paragraph 4 of Article 207 TFEU requires unanimity in certain instances, which apply only with regard to trade in services, FDI and commercial aspects of IP. Article 207(4) TFEU incorporates the rationale of the current provision and recognises the need for unanimity in these areas, which reflect aspects of the internal market where decision-making internally is sometimes subject to different voting requirements. ${ }^{71}$ However, this provision leaves less scope for ambiguities than Article 133(5)(4) TEC and adds significantly to the establishment of parallelism between internal and external powers at the procedural level.

More specifically, Article 207(4)(2) TFEU adopts a similar wording to current Article 133(5)(4)(1) TEC. It provides that:

For the negotiation and conclusion of agreements in the fields of trade in services and the commercial aspects of intellectual property, as well as foreign direct investment, the Council shall act unanimously where such agreements include provisions for which unanimity is required for the adoption of internal rules.

Bearing in mind that legislating in the internal market requires unanimity in specific fields, ${ }^{72}$ the drafters of the Lisbon Treaty also kept the derogation from the QMV rule, insofar as such "derogation" exists, internally. ${ }^{73}$

\footnotetext{
71 Hermann (n 15) 23; Cremona (n 15) 77-78.

72 For example unanimity is required in the internal market for the adoption of restrictions on freedom of establishment and services, for harmonisation of indirect taxation and approximation of laws.

73 Ceyssens (n 19) 284-285; Krajewski (n 6) 119-120.
} 
In contrast with the current regime, the Lisbon Treaty does away with the provision according to which unanimity is required for the negotiation and conclusion of international agreements on subject matters over which internal powers have not been exercised yet. This provision is highly controversial, in particular with regard to the determination of the internal rules that are necessary for avoiding unanimity and the assessment to what extent they should cover the topic of the proposed agreement. ${ }^{74}$ Furthermore, it breaches the principle of parallelism, as it allows a Member State to block international agreements on a subject matter even though it could not obstruct the adoption of internal legislation in that field. Abolishing this derogation from the QMV rule, the Lisbon Treaty establishes complete parallelism between internal and external competences and avoids the ambiguities that are raised with regard to the scope and extent of internal rules that currently need to exist in order for QMV to apply. ${ }^{75}$ Consequently, Article 207(4)(2) TFEU ensures that the balance between internal and external powers is kept, without, however, affecting the effectiveness of decision-making procedures.

In addition, Article 207(4)(3) TFEU requires unanimity for the negotiation and conclusion of international agreements 'in the field of trade in cultural and audiovisual services where these agreements risk prejudicing the Union's cultural and linguistic diversity' and 'in the field of trade in social, education and health services where these risk seriously disturbing the national organization of such services and prejudicing the responsibility of Member States to deliver them.' This provision resembles to a great extent the unanimity rule provided in current Article 133(6) TEC with regard to the same services sectors. However, subparagraph 3 of Article 207(4) TFEU does not require unanimity where trade in these services sectors is concerned. It is only when the conclusion of an international agreement poses risks to cultural and linguistic diversity and the national organisation and delivery of these services that unanimity is required. Consequently, this provision requires a risk assessment whenever trade in these services sectors is concerned. However, the Treaty does not provide the means on how such risk assessments should be conducted, and nor does it establish minimum levels of risk that should exist in order for unanimity to apply. ${ }^{76}$ Arguably, this ambiguity may result in the application of the unanimity rule in all cases concerning trade in these services sectors, thus recognising the concerns of a number of Member States who insisted on the inclusion of subparagraph 3 in the final text of Article 207(4) TFEU.

\footnotetext{
${ }_{74}$ For the interpretation of this provision see Hermann (n 15) 23-24; Krenzler and Pitschas (n 16) 305-306; Cremona (n 15) 77.

75 Krajewski (n 6Error! Bookmark not defined.) 121.

76 Ibid 122.
} 
In addition, Article 207 TFEU does not make any reference to horizontal agreements as Article 133 TEC does. The lack of a provision requiring unanimity in such cases should not be interpreted as abandoning the need for unanimity when unanimity is required for the adoption of part of an international agreement in accordance with subparagraphs 2 and 3 of Article 207(4) TFEU. ${ }^{77}$ On the contrary, it is arguable that in cases of international trade agreements dealing with a variety of subjects such as future WTO agreements, unanimity will be required for their negotiation and their conclusion, as long as they cover issues that fall under the unanimity rule.

\section{b) The role of the European Parliament}

The most important change brought by the Lisbon Treaty with regard to decision-making in the field of the Common Commercial Policy affects the institutional balance which has been struck, as it provides a more active role for the Parliament. Following the trend of granting a wider role to the Parliament and enhancing the legitimacy of external relations, Article 207 alongside Article 218 TFEU render the Parliament a co-legislator in the field of the Common Commercial Policy.

Article 207(2) TFEU expressly stipulates that the Parliament and the Council define the framework for the implementation of the Common Commercial Policy in accordance with ordinary legislative procedure. As Article 294 TFEU (ex Article 251 TEC) requires the consent of the Parliament for the adoption of internal legislation in accordance with ordinary legislative procedure, the conclusion can be drawn that Article 207(2) TFEU renders the Parliament a co-legislator in the field of the Common Commercial Policy as far as the adoption of autonomous measures is concerned..$^{78}$ In this regard, the Lisbon Treaty introduces a radical change to decision-making rules in the field of the Common Commercial Policy, as the Parliament acquires an indispensable role in its formation and implementation.

The consent of the Parliament is necessary not only for the adoption of autonomous measures, but also for the negotiation and conclusion of

\footnotetext{
77 The question whether unanimity is required not only in cases where the subject matters requiring unanimity form a substantial part of the proposed agreement but also in cases where they are ancillary to the main subject matter of the agreement, which was controversial under the previous regime (Hermann (n 15) 24; Cremona (n 15) 82), is not raised under Article 207 TFEU. The Lisbon Treaty does not provide a definition of horizontal agreements as 'agreements that concern also the areas that are covered by the unanimity rule' (emphasis added), thus indicating that unanimity is necessary not only when an agreement "concerns" a field where unanimous voting is required, but each time such a field is included in the agreement.

78 Krajewski (n 6) 123; Cremona (n 3) 30; Koutrakos (n 13) 150.
} 
international agreements, which is the basic means of action in the field of the Common Commercial Policy. ${ }^{79}$ Article 207(4) TFEU refers to Article $218 \mathrm{TFEU}$, which provides the general procedural rules for the adoption of all international agreements, while Article 218(1) TFEU recognises that its provisions apply to the negotiation and conclusion of all international agreements. Hence, Article 218 TFEU applies to trade agreements as well, subject to the procedural rules contained in Article 207 TFEU on the Common Commercial Policy. Given that Article 207 TFEU establishes in paragraphs 3 and 4 detailed rules concerning the negotiation of commercial policy agreements and decision-making in the Council, it is arguable that paragraph 6 of Article $218 \mathrm{TFEU}$, which concerns the role of the Parliament at the stage of the conclusion of international agreements, also applies to commercial policy agreements. ${ }^{80}$ The application of Article 218(6) TFEU to commercial policy agreements is further supported by the fact that this paragraph does not contain an explicit derogation for commercial policy agreements from its scope, as Article 300(3) TEC currently does.

Even though Article 218(6) TFEU grants as a rule a consultative role to the Parliament with regard to the negotiation and conclusion of international agreements, the consent of the Parliament is required in the specific cases enumerated in subparagraph (2)(a) of Article 218(6) TFEU. The last indent of Article 218(6)(2)(a) TFEU states that the consent of the Parliament is necessary for the conclusion of international agreements that cover 'fields to which either the ordinary legislative procedure applies, or the special legislative procedure where consent by the European Parliament is required'. Consequently, as the Common Commercial Policy is a field where the ordinary legislative procedure applies for the adoption of autonomous legislation, the consent of the Parliament is also required for the negotiation and conclusion of international agreements. ${ }^{81}$

Even though this provision establishes another form of "parallelism" between autonomous measures and international agreements, this time at the institutional level, it is arguable that it breaks the institutional balance between the internal and external competences of the Union. In the internal market, there are still areas to which the ordinary legislative

\footnotetext{
79 It is also noteworthy that Article 207(3) TFEU also grants a formal role to the Parliament at the stage of negotiation of international agreements, as it requires that the Commission reports to the Parliament during the negotiations of international trade agreements. This reference to the Parliament is new in the Lisbon Treaty and imposes a legal obligation on the Commission to inform the Parliament at the negotiations stage. However, given that the Commission already informs the Parliament on trade negotiations, this provision would only solidify the role of the Parliament during the negotiation of international agreements falling within the scope of the Common Commercial Policy.

80 Krajewski (n 6) 122-124.

81 Ibid.
} 
procedure does not apply and decision-making is assigned only to the Council. Even though the Treaty rules on establishment, services and capital make explicit references to the ordinary legislative procedure, ${ }^{82}$ Article 115 TFEU (ex Article 94 TEC) on approximation of laws relating to the movement of persons as well as Article 113 TFEU on indirect taxation grant only a consultative role to the Parliament. In this regard, the consent of the Parliament is required for the adoption of harmonising measures concerning the movement of persons and indirect taxation with regard to third countries within the framework of the Common Commercial Policy, even though the adoption of measures on the same subject matter within the framework of the internal market would not require the consent of the European Parliament.

Nevertheless, similar to the exclusive nature of Union competence, this derogation from parallelism appears necessary in order to ensure the effective application of the Common Commercial Policy. A common approach to decision-making can lead to the avoidance of inter-institutional conflicts and to the formation of a nuanced policy approach. In addition, the enhancement of democratic legitimacy of external economic relations beyond the degree of internal democratic legitimacy should be viewed positively, as it demonstrates the need for a more active role of the Parliament in economic affairs and external relations.

The simplification of the voting rules, mirroring internal market legislative procedures, and the establishment of the Parliament as a co-legislator indicate that the reform of the Common Commercial Policy concerns not only the scope and nature of Union competence but also its exercise. The integration of trade in goods, services, commercial aspects of IP and FDI is also accomplished with regard to decision-making in a clear and coherent manner, enabling the Union to exercise its powers more effectively in the future.

\section{Conclusions}

The Lisbon Treaty constitutes a benchmark in the evolution of the Common Commercial Policy and introduces a new era in EU external relations. Building upon the premises of the current regime, it contributes to the development of a coherent, effective and all-embracing Common Commercial Policy, and reflects the degree of internal economic integration in the field of external relations. The expansion of the scope of the Common Commercial Policy to trade in services, commercial aspects of IP and, most importantly, FDI indicates that a common policy in the fields of goods, services, establishment and capital with regard to third countries

82 Articles 49-53 (ex 43-47TEC), 56 (ex 49 TEC), 64 (57 TEC) TFEU make references to the ordinary legislative procedure. 
is needed in order to serve the goals of internal integration and to increase the competitiveness of Europe in the world. Merging the different areas of the Common Commercial Policy and simplifying the provisions concerning the exercise of EU competence, the Lisbon Treaty ensures its effective application in an increasingly globalised world. However, the "merger" of the different fields does not affect the balance of powers that exists in the internal market with regard to the same areas of law. On the contrary, Article 207 TFEU respects the delimitation of competence between the EU and Member States, as well as the institutional balance which is expressed in its decision-making provisions. Paragraphs 4 and 6 of Article 207 TFEU state in a simplified and clear manner that internal limitations on the scope and exercise of Union competence also exist with regard to trade and economic relations with third countries. The only derogations from parallelism between internal and external powers concern the exclusive nature of EU competence and the role of the European Parliament. However, they are both necessary for preserving the effectiveness of Union policy and bringing legitimacy to the most important field of EU external relations. 